\title{
FABRICATING A PROTOTYPE OF POTATO DIGGER TO SUIT SMALL HOLDINGS
}

\author{
Tawfik, M.A* and Y.S .Abdellah*
}

\begin{abstract}
A small size one-row prototype machine for digging potato was fabricated locally to be simple in design, low fabrication costs, ease to operate for digging, cleaning potato tubers in small holdings under sandy soil conditions. The practical experiments of this study were carried out to evaluate the performance of the machine under four forward speeds of 1.40,2.30,2.95 and $3.50 \mathrm{~km} / \mathrm{h}$, three blade rake angles of $10^{\circ}, 14^{\circ}$ and $20^{\circ}$ and three digging depths of 25,30 and $35 \mathrm{~cm}$ taking into consideration machine actual capacity, product losses, harvesting efficiency, cleaning efficiency, required energy and criterion cost of harvesting comparing with the manual method of harvesting(Hand hoe method).The obtained results revealed that the proper operating conditions for the prototype potato digger in small holdings are forward speed of $2.30 \mathrm{~km} / \mathrm{h}$, rake angle of $14^{\circ}$ and digging depth of $30 \mathrm{~cm}$ to achieve actual field capacity of $0.23 \mathrm{fed} / \mathrm{h}$ and the lowest percentage of total losses including $2.90 \%$ for the damaged tubers and $1.20 \%$ for the un-harvested tubers, high harvesting efficiency of $95.50 \%$ and the highest cleaning efficiency of $95.32 \%$ with minimum criterion costs of 381.32 LE/fed at required power of $16.42 \mathrm{~kW}$ and specific energy requirement of $71.39 \mathrm{kW/h}$.fed, but for the manual digging, the results showed that the average labor field capacity is $0.026 \mathrm{fed} / \mathrm{h}$, average harvesting efficiency is $82.51 \%$ and the average criterion cost is 1250.28 LE/fed. Hence, it can be concluded that the prototype digger is less for both losses and costs with high harvesting efficiency comparing with the manual method in small areas.
\end{abstract}

Keywords: small holdings, prototype, rake angle, criterion cost, hand hoe

\section{INTRODUCTION}

otato tubers are easily bruised or skinned so, harvesting is a
critical operation for the crop production because the type of
digger and separating techniques affecting bruising and consequently storing, marketing and trading of potato. In Egypt, the farmers have almost small

"Lecturer, Agric. Eng. Dept., Fac. of Agric., Zagazig Univ., Egypt. 
holdings so, the manual method of hand hoe for harvesting potato is widespread despite it needs a lot of labors, cost and time, on the other side; the large harvesting machines are uneconomical in those small areas. Kang and Halderson (1991) mentioned that the bulk harvesting machinery is generally insufficient in their energy utilization especially for harvesting major crops. Many investigations aimed to develop the performance of potato harvesting machines. Bishop and Maunder (1980) designed vibrating potato digger uses a full one-piece share on to which are attached closely-spaced tine bars which feed the tubers on a reciprocating riddle to separate soil and discharge the tubers on the ground. Generally, these machines are only suitable for the lighter soils. Younis (1987) tested one -row potato digger mounted on $51.50 \mathrm{~kW}$ tractor in sandy soil at different digging depths and speeds .The results revealed that the total losses was about $3 \%$ of the total yield compared with $8-14 \%$ for conventional harvesting method (Baladi plow).Srivastava et al. (1995) mentioned that the most widely used types of shares passive-shares. These shares are rigidly fixed to the frame and move with it. They added that the simplest in construction is the passive flat rectangular share. Abdel-Aal et al.(2002) modified a potato harvester to be suited for Egyptian farms. The optimum engineering parameters for the modified machine which achieved the highest undamaged, lowest damaged and losses were forward speed of $2.3 \mathrm{~km} / \mathrm{h}$, digger tilt angle of $14^{\circ}$, distance between the blade and elevator chain of $5 \mathrm{~cm}$, chain speed of $2.41 \mathrm{~m} / \mathrm{s}$, riddle speed of $4.63 \mathrm{~m} / \mathrm{s}$ and riddle inclination of $7^{\circ}$.Abdel Maksoud et al.(2004) developed the potato digger to be used for harvesting potato, separating them from soil and transporting tubers on a trailer outside the harvesting area. The experimental results reveal that the use of the developed potato digger maximize both of harvesting and cleaning efficiencies and minimize both losses and cost comparing with the same digger before development. They recommended to operate the digger at forward speed of $2.4 \mathrm{~km} / \mathrm{h}$, penetration angle of $14^{\circ}$ and adjust the separating sieve at slope angle of $8^{\circ}$.Therefore, such care should be given to establish a simple technique for harvesting potato to suit the small holdings of Egyptian farms with 
preventing the tuber quality and saving time, labor, energy and operational costs. Hence, the objectives of this study are:

1- Constructing a one-row mounted prototype machine for potato digging to suit the small holdings that could be attached to small tractors to save time, efforts and energy.

2- Evaluating the performance of the machine in the sandy soil and optimizing some operational parameters that including forward speed, rake angle, digging depth.

3- Comparing the prototype digging machine with the conventional digging method (hand hoe) in small areas from economic point of view.

\section{MATERIALS AND METHODS}

The field experiments were conducted at 6 October farms in Salhia ElGdeda Area,90 km Cairo-Ismalia Desert Road, Ismalia Governorate.

\section{A-Materials:}

\section{-Potato variety}

Experiments were carried out on potato crop (variety of Hermes). Potato tubers were planted mechanically using semi- automatic planter under row space of $70 \mathrm{~cm}$ with planting depth of $10 \mathrm{~cm}$ at forward speed of 2.8 $\mathrm{km} / \mathrm{h}$. On the other hand, irrigation and crop service operations were conducted according to the technical recommendations.

\section{-Soil moisture content}

Soil moisture content was measured at depth from 0-30 $\mathrm{cm}$ with an average value of $16 \%$ on d.b by using an oven at $105 \mathrm{C}^{\circ}$ for 24 hours. The mechanical analysis of the soil of the experimental site was carried out at Soil Science Dep., Faculty of Agriculture, Zagazig Univ., by using the hydrometer method. The mechanical analysis is shown in Table (1).

Table (1): Mechanical analysis of the soil in the experimental site

\begin{tabular}{|c|c|c|c|c|}
\hline $\begin{array}{c}\text { Soil Depth } \\
(\mathbf{c m})\end{array}$ & Clay (\%) & Silt (\%) & Sand (\%) & $\begin{array}{c}\text { Texture } \\
\text { class. }\end{array}$ \\
\hline $0-15$ & 8.19 & 14.26 & 77.55 & Sandy \\
$15-30$ & 11.08 & 17.12 & 71.80 & Sandy \\
\hline
\end{tabular}

\section{-Tractor}

A four wheels Kubota tractor standard type of $35 \mathrm{hp}(25.73 \mathrm{~kW})$ with three forward speeds was used to operate the prototype digger. The digger was mounted on the tractor by three-point hitching system and the P.T.O shaft provides the movement for the mobile parts. 


\section{- Prototype potato digger:}

\section{-The frame:}

The frame has a rectangular shape with cylindrical cross-section. The frame is made of steel iron with length of $160 \mathrm{~cm}, 90 \mathrm{~cm}$ in width with $65 \mathrm{~cm}$ height above the ground. The frame included elements to fix the digging blade, vibrating riddle, three point hitching system and drawbar to ease the mounting on the tractor hydraulic system and to secure the machine stability during operating as shown in Fig.(1). The prototype digger was carried by two ground wheels with $30 \mathrm{~cm}$ diameter and $12 \mathrm{~cm}$ thickness with possibility to adjust the distance between the two wheels to suit the space between ridges.

\section{The digging blade:}

The digging blade is a passive flat- rectangular blade with curved edge to ease penetrating the soil and lifting the tuber layer from ridges. The digging blade is made of iron steel with $55 \mathrm{~cm}$ length, $70 \mathrm{~cm}$ width and 6 $\mathrm{mm}$ thickness .The digging blade was attached with the frame by two rigid rods with possibility to adjust the rake angle by changing the position of the rode- end bolt on the frame.

\section{Vibrating riddle:}

The reciprocating riddle is used to sieve the potato tubers from their soil layer and transfer the tubers behind the machine. The reciprocating riddle consists of parallel rubber-coated bars to prevent potato tubers from bruising. The bars are made of iron steel with $3 \mathrm{~mm}$ diameter and welded to two curved rulers. The riddle was made with $100 \mathrm{~cm}$ length, $70 \mathrm{~cm}$ width at the front and $35 \mathrm{~cm}$ width at the rear. The riddle was carried by four swinging holders to provide the riddle with the forth back movement. At the front, the curved ruler attached rigidly to reciprocating beam by two vertical swinging holders. The beam is made of iron with $55 \mathrm{~cm}$ length, $10 \mathrm{~cm}$ width and $3 \mathrm{~mm}$ thickness fitted to the frame by greased bearing. At the rear, the curved ruler attached with another two vertical swinging holders. These holders are hanging freely to move as a pendulum. The motion of the vibrating riddle mainly provided from the reciprocating motion of the beam. 
Transmission system: As shown in Fig.(2), the prototype machine is operated by the tractor P.T.O shaft using universal joint. The transmission system mainly consists of:

\section{-The crank and connected rod}

The crank and the connected rod are the main responsible parts that convert the rotating motion of the tractor P.T.O shaft to rocker arm. The crank was carried by cylindrical roller bearing fixed to a cross- bar beam with inner diameter of $50 \mathrm{~mm}$. The connected rod is made of iron with 40 $\mathrm{cm}$ length and $4 \mathrm{~mm}$ in diameter. The connected rod was fitted to crank through two bolts (M12) at the bottom end but, the top end was welded to the rocker arm.

\section{-The rocker arm}

The main job of the rocker arm is transferring and converting the straight vertical motion of the connected rod to a reciprocating motion on the beam. The rocker arm is made of iron in curved shape. The both ends of the rocker arm were welded rigidly to the connected rod and the reciprocating beam.

\section{The reciprocating beam:}

It was necessary to transfer and convert the motion of the rocker arm to vibrating motion for riddle. It is a rectangular steel beam, fitted directly to the frame and holded on bearings to permit of its reciprocated motion.

\section{B-Methods:}

The experimental site was about 12 feddans divided into two plots:

-The first one is 9 feddans for mechanical digging and which divided into 3 equal subplots ( 3 feddans) and each subplot was divided into four equals areas( 0.75 feddan) to operate the digger at every forward speed with one value of rake angle and digging depth.

-Second one is 3 feddans for manual digging using hand hoe.

The performance of potato digger was evaluated at constant value of riddle inclination of $8^{\circ}$ (According to the primarily tests), these parameters are:

1-Four forward speeds of 1.40, 2.30, 2.95 and $3.50 \mathrm{~km} / \mathrm{h}$.

2-Three values of blade rake angle of $10^{\circ}, 14^{\circ}$ and $18^{\circ}$.

3 - Three values of digging depth of 25,30 and $35 \mathrm{~cm}$. 

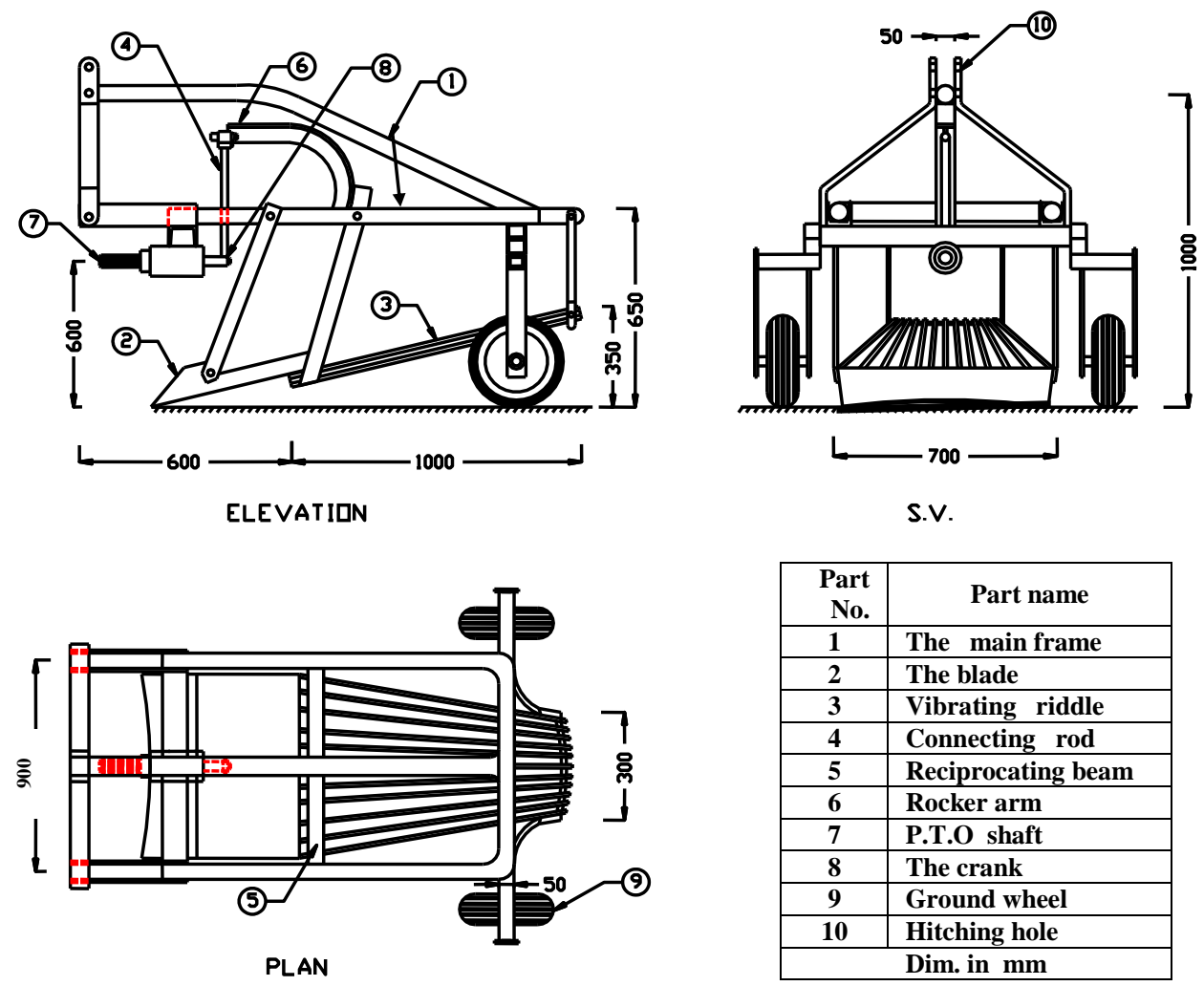

\begin{tabular}{|c|l|}
\hline $\begin{array}{r}\text { Part } \\
\text { No. }\end{array}$ & \multicolumn{1}{|c|}{ Part name } \\
\hline 1 & The main frame \\
\hline 2 & The blade \\
\hline 3 & Vibrating riddle \\
\hline 4 & Connecting rod \\
\hline 5 & Reciprocating beam \\
\hline 6 & Rocker arm \\
\hline 7 & P.T.O shaft \\
\hline 8 & The crank \\
\hline 9 & Ground wheel \\
\hline 10 & Hitching hole \\
\hline & Dim. in mm \\
\hline
\end{tabular}

Fig.(1):Elevation, plan and right side view of the prototype digger.

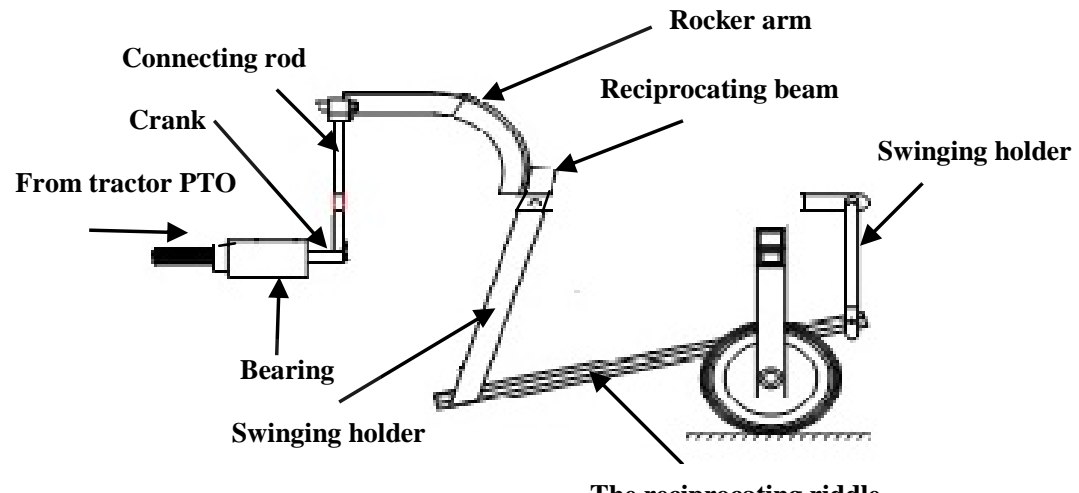

Fig.(2): The transmission system of the prototype digger. 


\section{C-MEASUREMENTS:}

Evaluation of the prototype machine was performed taking into consideration the following indicators:

\section{Digger and labor field capacity $\left(\mathbf{F C}_{\text {act }}\right)$}

The actual field capacity of the potato digger and labor were calculated by using the following equations:

$$
\mathrm{FC}_{M \mathrm{ach}}=\frac{A_{o}}{T_{c}} \quad, \quad \mathrm{FC}_{L a b}=\frac{A_{L}}{T_{c}}
$$

$\mathrm{FC}_{\text {Mach }}, \mathrm{FC}_{\mathrm{Lab}}=$ actual field capacity of the potato digger and labor, fed/h.

$A_{O}, A_{L}=$ harvested area by digger and labor, feddan.

$\mathrm{T}_{\mathrm{c}}=$ total consumed time, $\mathrm{h}$.

\section{Fuel consumption}

Fuel consumption was calculated as follows:

$$
F_{\text {cons }}=\frac{V_{f}}{T} \times 3.6
$$

Where:

$\mathrm{F}_{\mathrm{c}}=$ Rate of fuel consumption $(\mathrm{L} / \mathrm{h})$

$\mathrm{V}_{\mathrm{f}}=$ Volume of fuel consumed $\left(\mathrm{cm}^{3}\right)$

$\mathrm{T}=$ Time of harvesting $(\mathrm{s})$

\section{Harvesting efficiency $\left(\boldsymbol{\eta}_{\mathbf{H}}\right)$}

The harvesting efficiency can be calculated by the following equation:

Harvestingeffciency $(\eta \mathrm{H}), \%=\frac{\text { mass of un-damaged raised tuberin sample }}{\text { mass of the total sample }} \times 100$

\section{4- Tubers total losses:}

Tubers total losses are the damaged tubers which including the peeled ,injured and scuffed tubers and the un-harvested tubers (buried tubers).

\section{Cleaning efficiency $\left(\eta_{\mathbf{C}}\right)$}

The cleaning efficiency can be determined by the following equation:

$\frac{\text { Mass of cleaned tubers in sample }}{\text { Mass of the total raised sample }} \times 100$ Cleaning efficiency $\left(\eta_{\mathrm{C}}\right), \%=$

\section{Harvesting power and energy requirement:}

The harvesting power $\left(\mathrm{P}_{\mathrm{H}}\right)$ was estimated by the following formula (Hunt 1980): 


$$
P_{H}=\left[\mathrm{F} . \mathrm{C}(1 / 3600) P E \cdot L C V \cdot 427 \cdot \xi_{t h b} \cdot \xi_{m} \cdot 1 / 75.1 / 36\right], \mathrm{kW}
$$

Where: $\mathrm{F} . \mathrm{C}=$ Fuel consumption, $(\mathrm{lit} / \mathrm{h})$

P.E= Fuel density (for solar $0.85 \mathrm{~kg} / \mathrm{m}^{3}$ )

$\mathrm{LCV}=$ Calorific value of fuel $(11000 \mathrm{k} . \mathrm{cal} / \mathrm{kg})$

$\xi_{t h b} .=$ Thermal efficiency of engine (35\% for diesel engine)

$\xi_{m}=$ Mechanical efficiency of the engine (85\%)

The specific energy requirements $(\mathrm{kW} . \mathrm{h} / \mathrm{fed})$ was calculated by using the following equation:

The specific energy requirement $(\mathrm{kW} . \mathrm{h} / \mathrm{fed})=\frac{\text { Harvesting power }(\mathrm{kW})}{\text { Actual harvesting capacity }(\mathrm{fed} / \mathrm{h})}$

\section{Criterion cost of harvesting:}

Operationa $l$ cost of mechanical digging $(\mathrm{L} . \mathrm{E} / \mathrm{fed})=\frac{(\text { Tractor }+ \text { machine }) \text { hourly cost }(\mathrm{L} . \mathrm{E} / \mathrm{h})}{\text { Actual capacity }(\mathrm{fed} / \mathrm{h})}$

The criterion cost of mechanical harvesting = Operational cost of machines $($ LE/fed $)+$ cost of losses $($ LE/fed $)+$ manual collecting costs (LE/fed)

The machine cost was determined by using the following formula (Awady et al., 2003):

$\mathrm{C}=\frac{\mathrm{P}}{\mathrm{h}}\left(\frac{1}{\mathrm{E}}+\frac{\mathrm{I}}{2}+\mathrm{T}+\mathrm{R}\right)+(0.9 \mathrm{~W} . \mathrm{S} . \mathrm{F})+\frac{\mathrm{M}}{144}$, (L.E./h)

Where:

C: Machine hourly cost, L.E./h.

P: Price of machine, L.E.

$\mathrm{h}$ : Yearly working hours.

E: Life expectancy of the machine, year.

I: Interest rate/year.

T: Taxes and over heads ratio, $\%$.

$\mathrm{R}$ : Repairs and maintenance ratio, $\%$.

$\mathrm{W}$ : Power, $\mathrm{kW}$.

S: specific fuel consumption, (L/kW.h).

$\mathrm{F}=$ Fuel price, (L.E).

$\mathrm{M}=$ Operator monthly salary, (L.E).

$0.9=$ Factor accounting for ratio of rated power and lubrications.

$144=$ The monthly average working hours. 
-The criterion cost of hand hoe method was calculated as follows:

The operational cost of manual harvesting = Operational cost of manual digging $(L E / f e d)+$ Cost of losses $(L E / f e d)+$ Average manual collecting costs (LE/fed)

Opeartional $\cos t$ of manual digging $(\mathrm{L} . \mathrm{E} / \mathrm{fed})=\frac{\text { Digging hourly cost }(\mathrm{L} . \mathrm{E} / \mathrm{h})}{\text { Average labor field capacity }(\mathrm{fed} / \mathrm{h})}$ In the manual harvesting treatments 8 labors per day were used for digging (4 labors) and collecting potato tubers (4 labor).

Digging hourly cost $(\mathrm{LE} / \mathrm{h})=$ No. of labor(4 labors/fed $) \times$ Daily digging wage $(60 \mathrm{LE} /$ day $) /$ Daily working hours $(8 \mathrm{~h})=4 \times 60 / 8=30 \mathrm{LE} / \mathrm{h}$ Average manual collecting costs $(\mathrm{LE} / \mathrm{fed})=$ No. of collecting labors $(4$ labors/fed) $x$ Daily collecting wage $(40 \mathrm{LE} / 8 \mathrm{~h})=4 \times 40=160 \mathrm{LE} / \mathrm{fed}$

\section{RESULTS AND DISCUSSION}

The obtained results were discussed under the following topics:

\section{1-Effect of forward speed and rake angle on machine actual field capacity at different digging depths}

It is known that the forward speed is playing an important role for determining the actual field capacity. Fig.(3) showed that ,the increase of forward speed from 1.4 to $3.50 \mathrm{~km} / \mathrm{h}$, the machine actual field capacity increased rapidly, but the contrarily was occurred by increasing the rake angle. It is noticed the highest value of machine field capacity of 0.46 $\mathrm{fed} / \mathrm{h}$ was achieved at the high forward speed of $3.5 \mathrm{~km} / \mathrm{h}$, low rake angle of $10^{\circ}$ and digging depth of $25 \mathrm{~cm}$, but with a great increase in tubers losses due to the floating of digging blade, while the lowest value of 0.14 $\mathrm{fed} / \mathrm{h}$ was recorded at low forward speed of $1.40 \mathrm{~km} / \mathrm{h}$, high rake angle of $20^{\circ}$ and digging depth of $35 \mathrm{~cm}$ due to the increase of tractor wheels slippage with a clear increase in tuber losses. It is clear that the forward speed of $2.30 \mathrm{~km} / \mathrm{h}$, rake angle of $14^{\circ}$ and digging depth of $30 \mathrm{~cm}$ will be the optimum operating conditions that gave an acceptable value of machine actual field capacity $(0.23 \mathrm{fed} / \mathrm{h})$. Generally, the optimum value of field capacity that will record at the highest values of harvesting efficiency, cleaning efficiency and low values of tubers losses, required energy and costs. 

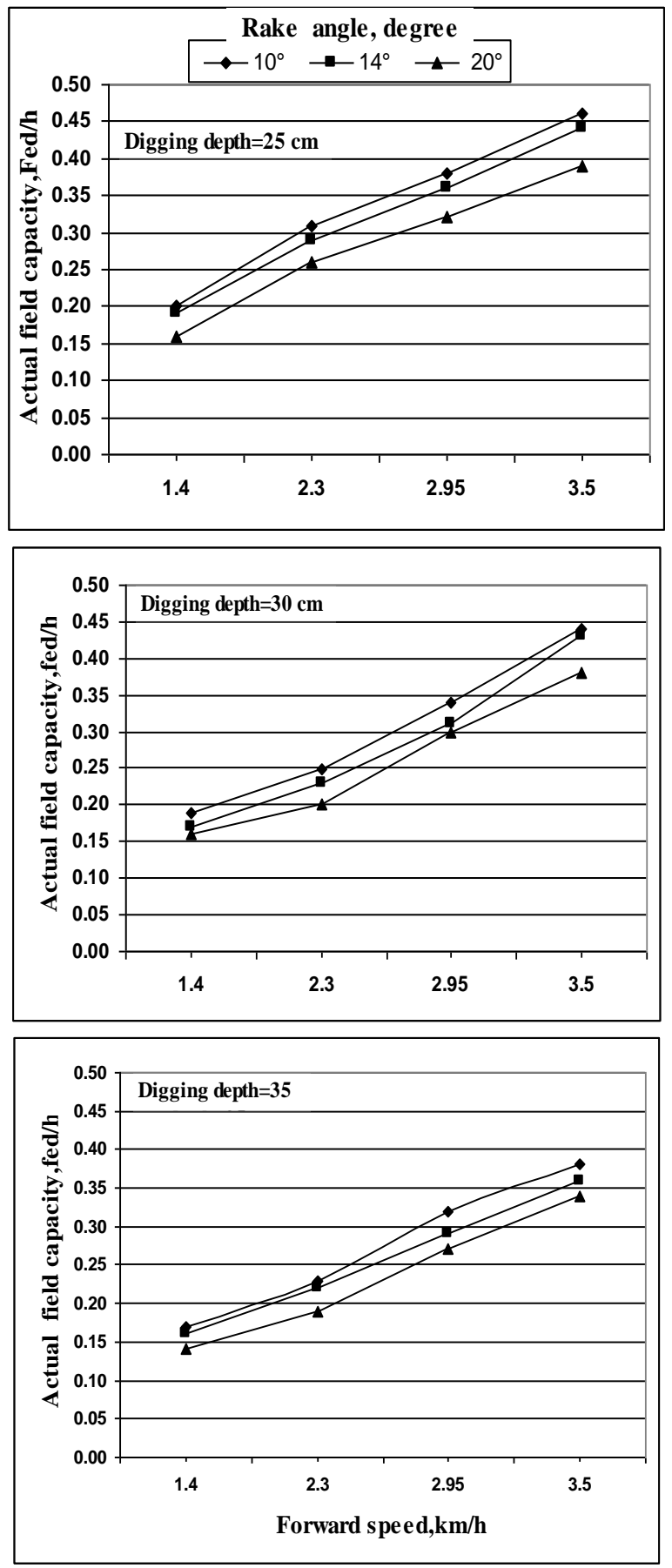

Fig.(3) :Effect of forward speed and rake angle on actual field capacity at different digging depths. 


\section{2-Effect of forward speed and rake angle on Total losses at different digging depths}

Fig.(4) showed that tuber total losses (damaged and un-harvested tubers) were increased by increasing the forward speeds. It was found that the lowest percentages of damaged tubers of 2.14 and $2.90 \%$ were recorded at forward speeds of 1.4 and $2.30 \mathrm{~km} / \mathrm{h}$, rake angle of $14^{\circ}$ and digging depth of $30 \mathrm{~cm}$, while the highest percentage of damaged tubers of $9.60 \%$ was recorded at forward speed of $3.50 \mathrm{~km} / \mathrm{h}$ at rake angle of $10^{\circ}$ and digging depth of $25 \mathrm{~cm}$. The highest percentage of the damaged tubers at high forward speed and low rake angle can be attributed to the floating of the digger's blade and the unsteady flow of soil layer on the blade so, a high friction will be expected and a clear increase in damaged tubers percentage will be noticed. Regarding to the effect of forward speed, rake angle and digging depth, the increase of forward speed from 1.40 to $2.30 \mathrm{~km} / \mathrm{h}$ at rake angle of $14^{\circ}$ was followed with a little increase of the un-harvested tubers percentage, but any further increase in forward speed the un-harvested tuber will increase. The highest percentage of the un-harvested tubers of 7.98, 5.80 and $4.42 \%$ were recorded at forward speed of $3.5 \mathrm{~km} / \mathrm{h}$ and rake angle of $10^{\circ}$ for digging depths of 25,30 and $35 \mathrm{~cm}$ respectively, this is may be attributed to the circulating motion of soil on the digging blade resulting in a great variation in the digging depth. Despite the high digging depth of $35 \mathrm{~cm}$ gave the lowest values of the un-harvested tuber but a clear increase in tubers damaged was occurred, this may be attributed to the highly increase of friction between the tubers and the great amount of soil especially at the high values of soil moisture content. The lowest percentage of total losses including $2.90 \%$ for the damaged tubers and $1.20 \%$ for the un-harvested tubers were recorded at forward speed of $2.30 \mathrm{~km} / \mathrm{h}$, rake angle of $14^{\circ}$ and digging depth of $30 \mathrm{~cm}$.

\section{3-Effect of forward speed and rake angle on harvesting efficiency at different digging depths}

The harvesting efficiency mainly depends upon the un-damaged tubers percentage in the raised yield. Fig.(4) display that highest values of harvesting efficiency were achieved at low forward speeds of 1.40 and $2.3 \mathrm{~km} / \mathrm{h}$ at digging depth of $30 \mathrm{~cm}$. The obtained results indicated that the 

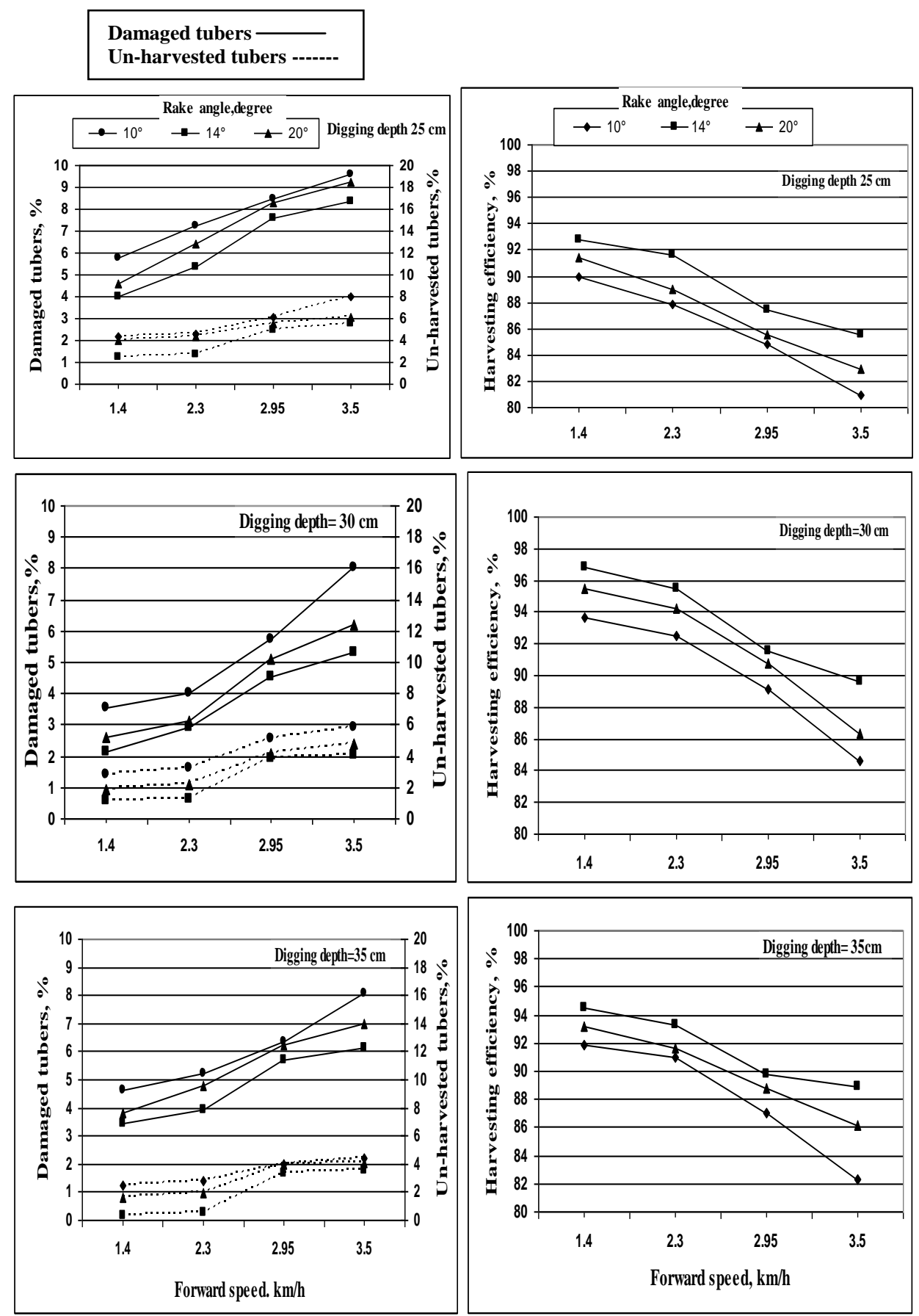

Fig.(4): Effect of forward speed and rake angle on tubers losses and the harvesting efficiency at different digging depths. 
increase of forward speed from 1.40 to $2.30 \mathrm{~km} / \mathrm{h}$ the harvesting efficiency decreased by $10,7.80$ and $9.22 \%$ for rake angles of $10^{\circ}, 14^{\circ}$ and

$20^{\circ}$ respectively. The highest harvesting efficiencies of 96.86 and $95.50 \%$ were achieved at low forward speeds of 1.40 and $2.30 \mathrm{~km} / \mathrm{h}$ respectively at rake angle of $14^{\circ}$ and digging depth of $30 \mathrm{~cm}$. This can be attributed to the increase of the damaged (scuffed, peeled and injured) tubers percentage in the raised yield by increasing the forward speed at all of operating parameters, in the same time, the lowest value of harvesting efficiency of $80.90 \%$ was recorded at high forward speed of $3.5 \mathrm{~km} / \mathrm{h}$, low rake angle of $10^{\circ}$ and digging depth of $25 \mathrm{~cm}$, because the decrease of both digging angle and digging depth especially at high forward speed will decrease the raised potato soil layer which leads to the direct impact between the blade and tubers so, more damaged tubers will be expected. Also, digging depth of $35 \mathrm{~cm}$ gave low values of harvesting efficiency; this may be attributed to the clear increase tuber losses due to the friction between tubers and soil. It can be concluded that the forward speed of $2.30 \mathrm{~km} / \mathrm{h}$, rake angle of $14^{\circ}$ and digging depth of $30 \mathrm{~cm}$ are the optimum operating conditions.

\section{4-Effect of forward speed and rake angle on cleaning efficiency at different digging depths}

Cleaning efficiency is considered one of the most important indicators of tuber quality. Fig.(5) illustrated that highest value of cleaning efficiency of $95.32 \%$ was achieved at forward speed of $2.30 \mathrm{~km} / \mathrm{h}$, rake angle of $14^{\circ}$ and digging depth of $30 \mathrm{~cm}$. The results showed that by increasing the forward speed from 1.40 to $2.30 \mathrm{~km} / \mathrm{h}$ the cleaning efficiency increased by $2.06,3.98$ and $1.12 \%$ for digging depths of 25,30 and $35 \mathrm{~cm}$ respectively at rake angle of $14^{\circ}$, but increasing forward speed from 2.4 to $3.5 \mathrm{~km} / \mathrm{h}$ was followed with a decrease of cleaning efficiency by 7.53 , 6.29 and $8.88 \%$ for digging depths of 25,30 and $35 \mathrm{~cm}$ respectively, also, the results showed that the lowest value of cleaning efficiency of $72.64 \%$ was recorded at high forward speed of $3.5 \mathrm{~km} / \mathrm{h}$, low rake angle of $10^{\circ}$ and digging depth of $35 \mathrm{~cm}$. The increase of cleaning efficiency by increasing forward speed from 1.40 to $2.30 \mathrm{~km} / \mathrm{h}$ can be attributed to the machine's riddle still able to sieve and separate tubers from the soil but 
any further increase in speed the ability of machine to clean and separate tuber will decrease. Also increasing in digging depth up to $35 \mathrm{~cm}$ and low rake angle of $10^{\circ}$ gave worst cleaning efficiency due to the lodging effect of the great amounts of soil which exceed the riddle ability for sieving. From this point, it is recommended to use the machine at forward speed of $2.30 \mathrm{~km} / \mathrm{h}$, rake angle of $14^{\circ}$ and digging depth of 30 $\mathrm{cm}$.

\section{5-Effect of forward speed and rake angle on power and energy requirements at different digging depths}

The energy requirements depend upon the consumed power as well as fuel consumption and the actual field capacity. As illustrated in Fig.(5), the specific energy consumption decreases by increasing the forward speed and the contrarily was occurred with the consumed power. This decrease can be attributed to the increase of the actual field capacity compared with the increase of the consumed power when the forward speed increased from 1.40 to $3.5 \mathrm{~km} / \mathrm{h}$.It is noticed that the lowest value of specific energy consumption of $37.24 \mathrm{~kW} / \mathrm{h}$.fed was achieved at forward speed of $3.5 \mathrm{~km} / \mathrm{h}$, rake angle of $10^{\circ}$ and digging depth of $25 \mathrm{~cm}$, while the highest value of specific energy consumption of 117.86 $\mathrm{kW} / \mathrm{h}$.fed was recorded at forward speed of $1.40 \mathrm{~km} / \mathrm{h}$, rake angle of $20^{\circ}$ and digging depth of $35 \mathrm{~cm}$. The obtained results indicated that the increase of specific energy consumption by increasing both rake angle from $10^{\circ}$ to $20^{\circ}$ and digging depth from 25 to $35 \mathrm{~cm}$ may be referred to the great load on the tractor motor to overcome the soil resistance during cutting the potato soil layer resulting in a high increase in the consumed fuel as well as power compared with the increase of the field capacity. Hence, the optimum operating conditions of forward speed of $2.3 \mathrm{~km} / \mathrm{h}$, rake angle of $14^{\circ}$ and digging depth of $30 \mathrm{~cm}$ at power consumption of $16.42 \mathrm{~kW}$ and energy of $71.39 \mathrm{~kW} . \mathrm{h} / \mathrm{fed}$.

\section{6-Effect of forward speed and rake angle on criterion cost of mechanical harvesting at different digging depths}

The criterion cost of the mechanical harvesting is mainly including digging cost, manual collecting cost and product losses cost. Fig.(6) showed that the lowest criterion costs were achieved at rake angle of $14^{\circ}$. It was noticed that increasing of forward speed from 1.40 to $2.30 \mathrm{~km} / \mathrm{h}$ at rake angle of $14^{\circ}$ decreased the criterion cost by $5.4,11.25$ and $9.38 \%$ 

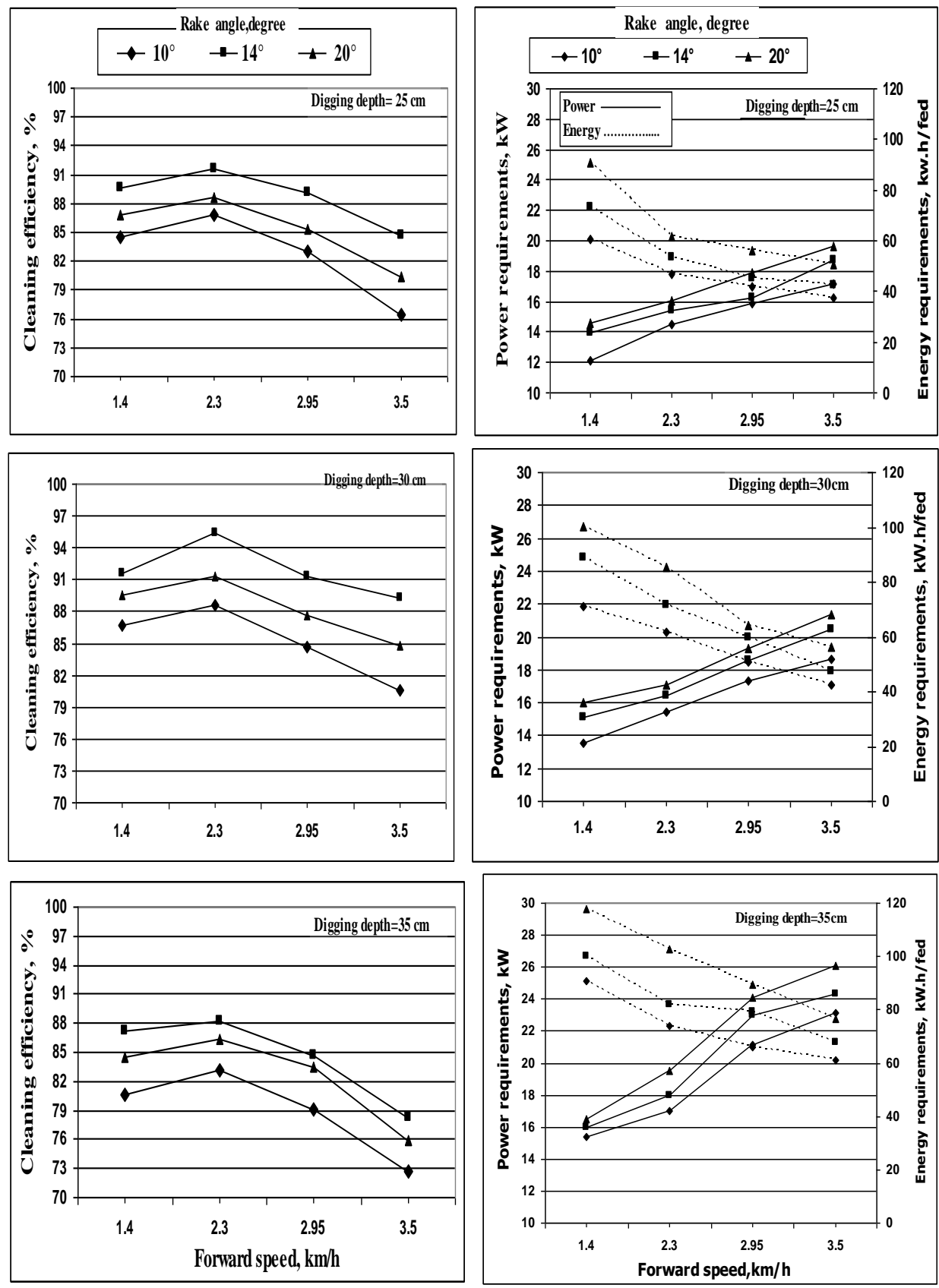

Fig.(5): Effect of forward speed and rake angle on cleaning efficiency, power and energy requirements at different digging depths. 
for digging depths of 25,30 and35 $\mathrm{cm}$ respectively, but any further increase in forward speed the criterion costs will increase rapidly. This decrease can be attributed to the increase of actual field capacity of machine in rang of 1.40 to $2.30 \mathrm{~km} / \mathrm{h}$ and any increase in forward speed will increase the product losses cost. The obtained results showed that the highest criterion cost of $484.65 \mathrm{LE} /$ fed was recorded at rake angle of $20^{\circ}$ at forward speed of $3.5 \mathrm{~km} / \mathrm{h}$ and digging depth of $25 \mathrm{~cm}$, this may be due to the decrease of field capacity at low rake angles and the clear increase in potato losses costs at shallow depths. From the obtained results, the lowest criterion cost of $381.32 \mathrm{LE} / \mathrm{fed}$ was recorded at forward speed of $2.30 \mathrm{~km} / \mathrm{h}$, rake angle of $14^{\circ}$ and digging depth of $30 \mathrm{~cm}$.

\section{7-The manual digging using hand hoe}

All results of manual harvesting treatments in this study is not absolute values because it depends upon different factors such as; the state of weather, type of soil, number of labors ,the muscular strength, health and mental state of labor, but it is considered an indicator of manual harvesting process. As illustrate in Fig.(7-a), it is noticed that the average labor field capacity is about $0.026 \mathrm{fed} / \mathrm{h}$. The highest labor field capacity of $0.032 \mathrm{fed} / \mathrm{h}$ attained at the beginning of the day and the field capacity started in increasing from 0.025 to $0.027 \mathrm{fed} / \mathrm{h}$ after the break and too sharp drop in field capacity from 0.027 to $0.020 \mathrm{fed} / \mathrm{h}$ was observed at the end of the working day .This drop can be attributed to the muscular fatigue of labor. Fig.(7-b) showed that the average manual harvesting efficiency of $82.51 \%$ is considered a low efficiency comparing with the mechanical digging due to the increase of the scuffed and injured tubers because the depth of the hoe's impacts during digging is not equal in addition to labor's retiring especially at the last hours of working. Fig.(7c) showed that the average criterion cost of manual digging was about 1250.28 LE/fed. The high cost of manual digging is due to the sharp reduction of manual field capacity during working day and the increase of product losses costs, in addition to the manual digging field capacity is very low comparing with the mechanical digging. 

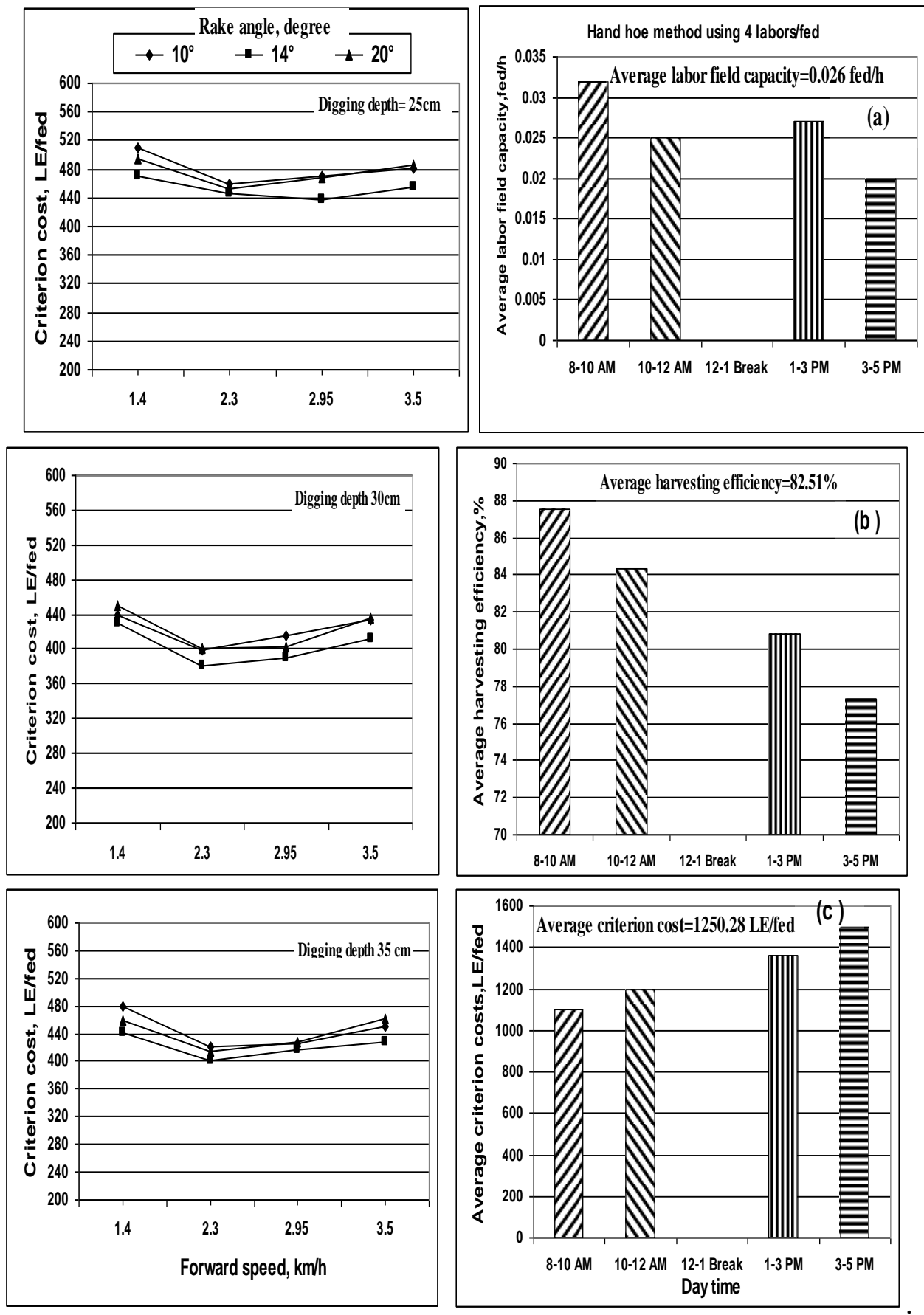

Fig.(6):The criterion cost for mechanical harvesting.

Fig.(7): Manual harvesting 


\section{CONCLUSION}

According to the obtained results, the proper operating conditions for the prototype potato digger in small holdings are forward speed of $2.30 \mathrm{~km} / \mathrm{h}$ , rake angle of $14^{\circ}$ and digging depth of $30 \mathrm{~cm}$ to achieve actual field capacity of $0.23 \mathrm{fed} / \mathrm{h}$ and the lowest percentage of total losses including $2.90 \%$ for the damaged tubers and $1.20 \%$ for the un-harvested tubers, high harvesting efficiency of $95.50 \%$ and the highest cleaning efficiency of $95.32 \%$ with minimum criterion costs of 381.32 $\mathrm{LE} / \mathrm{fed}$ at required power of $16.42 \mathrm{~kW}$ and specific energy requirement of $71.39 \mathrm{~kW} / \mathrm{h}$.fed ,but for the manual digging, the results showed that the average labor field capacity is about $0.026 \mathrm{fed} / \mathrm{h}$, average harvesting efficiency is $82.51 \%$ and the average criterion cost is $1250.28 \mathrm{LE} / \mathrm{fed}$. Hence, it can be concluded that the prototype digger is less for both losses and costs with high harvesting efficiency comparing with the manual method at small areas.

\section{REFERENCES}

Awady, M.N., I. Yehia, M.T. Ebaid and E.M. Arif, 2003. Development and theory of rice cleaner for reduced impurities and losses. Misr J. Ag. Eng., 20(4) : 53-68.

Abdel-Aal, S.E., M.S. El-Shal , M.K. Abdel-Wahab and A.A. AbdelBary, 2002. Development of potato harvester suitable for Egyptian farms. Misr J. Ag. Eng., 19 (3): 643-656.

Abdel Maksoud,S.E., M.M. Morad and H.A. Morghany, 2004. Development of a combination unit for harvesting and gathering potato crops .Zagazig J. of Agr.Res., 31(2): 699:718.

Bishop, C.F.H., and W.F., Maunder, 1980. Potato mechanization and storage. Farming Book Press Limited, Ipswich Sufflok, UK. ISBN 0-85236-106-2. 
Hunt, R. D. 1983. Farm power and machinery management. 9th ed.,Cushing-Malloy Inc.,NY.

Ibrahim, M.M, A.E. Abou-Elmagd, Z.E.Ismail and M.A. ElSaadany.1989. Estimation the performance of developed digger to harvest sugar beet. Egyptian-German Conf. in Agric.Mech., 4-6 October.

Kang,W. S. and J.L. Halderson, 1991. A vibratory two-row potato digger.Applied Engineering in Agriculture 7(6): 683-687.

Srivastava, A. K., C.E. Goering and R.P. Rohrbach, 1995. Theory construction calculation of Agricultural machines. American Society of Agric. Eng.,Pemela De Vore Hansen, Editor Books \& Journals.

Younis, S. M., 1987. Mechanization of potato harvesting with minimum losses. Alexandria Journal of Agricultural Research v32 (3) p (110),Egypt.

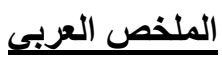

تصنيع نموذج آلة لتقليع محصول البطاطس تتناسب مع الحيازات الصغيرة

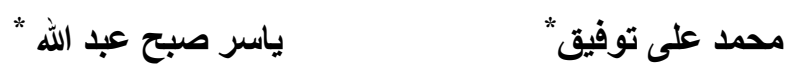

تم تصنيع نموذج مصغر لآلة لتقليع محصول البطاطس محلياً بحيث تكون بسيطة التصميم ،

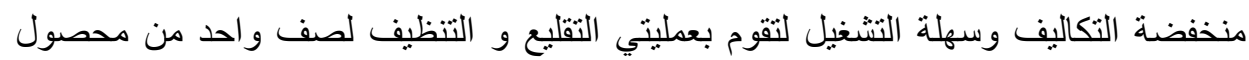

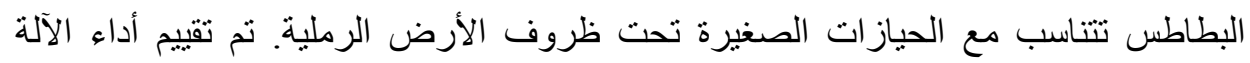

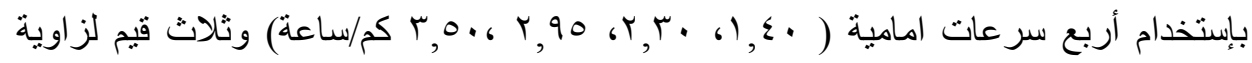

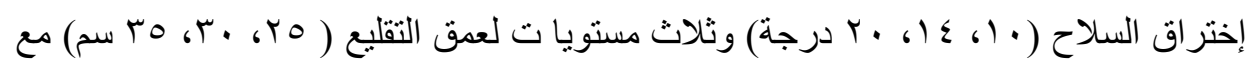

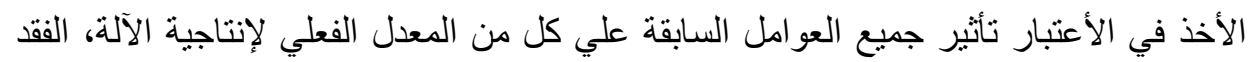

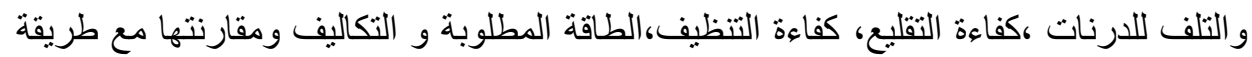
التقليع اليدوية بإستخدام الفأس البلدي.

* مدرس الهندسة الزراعية ـ كلية الزراعة - جامعة الزقازيق- مصر. 
وقد أوضحت نتائج الدراسة أن أفضل عو امل التشغيل للآلة تحت ظروف الحياز ات الصغيرة

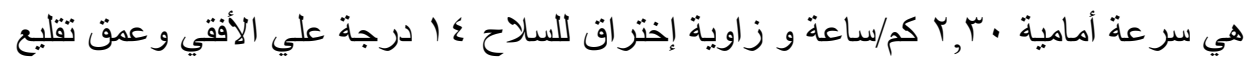

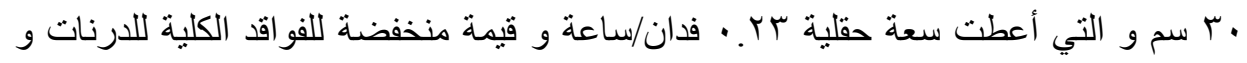

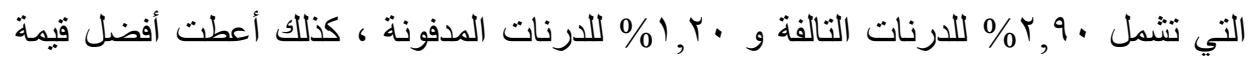

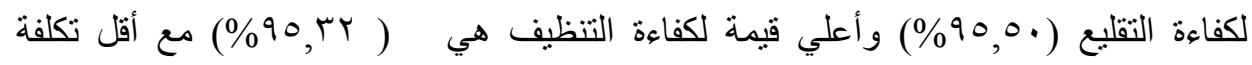
VI.rq (T) كيلووات/فدان.ساعة).ولكن بالنسبة لطريقة التقليع اليدوية فإن النتائج أشارت إلي أن أن منوسط

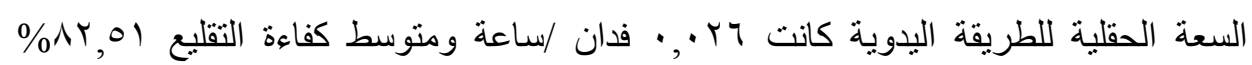

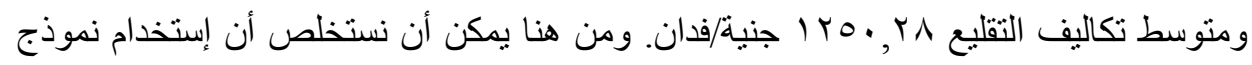

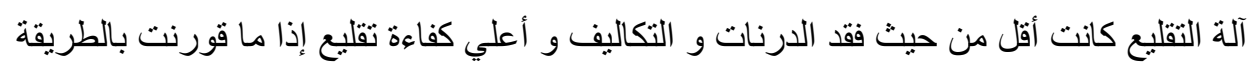
اليدوية بإستخدام الفأس البلدي في الحياز ات الصغيرة. 